influenza A (H1N1) virus infection-Mexico, March-April 2009. MMWR Morb Mortal Wkly Rep 2009; 58:467-470.

2. Cunha BA, Pherez FM, Klein NC, et al. Swine influenza (H1N1) screening tests: problems \& inconsistencies. Eur J Clin Microbiol Infect Dis 2009 (in press).

3. Cunha BA, Pherez FM, Strollo S. Swine influenza (H1N1): diagnostic dilemmas early in the pandemic. Scand J Infect Dis 2009 (in press).

4. Cunha BA, McDermott BP, Mohan SS. The diagnostic and prognostic significance of relative lymphopenia in adult patients with influenza $A$. Am J Med 2005; 118:1307-1309.

5. Cunha BA, Pherez FM, Schoch P. The diagnostic importance of relative lymphopenia as a marker of swine influenza $(\mathrm{H} 1 \mathrm{~N} 1)$ in adults. Clin Infect Dis 2009; 49:1454-1456.

6. Criswell S, Couch BS RB, Greenberg SB, et al. The lymphocyte response to influenza in humans. Am Rev Respir Dis 1979; 120:700-704.

7. Van Campen H, Easterday BC, Hinshaw VS. Destruction of lymphocytes by a virulent avian influenza A virus. J Gen Virol 1989; 70:467-472.

8. Tumpey TM, Lu X, Morken T, et al. Depletion of lymphocytes and diminished cytokine production in mice infected with a highly virulent influenza A (H1N1) virus isolated from humans. J Virol 2000; 74:6105-6116.

\section{Legionnaires Disease-Reordered}

To the Editor-Legionnaires disease can be classified into 3 exposure categories depending on the assumed environment of the exposure that led to infection: community-acquired Legionnaires disease, travel-associated Legionnaires disease, and nosocomially acquired Legionnaires disease. The disease frequency of Legionnaires disease by category is commonly presented as a proportion of cases of Legionnaires disease classified according to type of exposure among all cases for which exposure category is reported. In European countries, most cases of Legionnaires disease during the period from 2004 through 2006 were community acquired (66\%); few- er were travel associated $(27 \%)$ or nosocomially acquired $(7 \%))^{1,2}$ However, this representation does not take into account the number of person-days at risk within the exposure types. The number of cases divided by the number of persondays at risk is the incidence and should give another perspective on the likelihood of individuals to acquire Legionnaires disease when exposed within these categories.

We examined German data on cases of Legionnaires disease that were reported to the Robert Koch-Institute during the period from 2004 through 2006. These were classified in the following 4 categories: community-acquired Legionnaires disease, travel-associated Legionnaires disease, nosocomially acquired Legionnaires disease, and Legionnaires disease acquired in a nursing home. We obtained data on person-days at risk from the Federal Statistical Office, Wiesbaden, Germany.-5 To determine the number of days that the population was hospitalized or spent in nursing homes, we used occupancy data (Table 1). Travel data were received in the form of number of nights that adults spent away from home for private or occupational purposes. ${ }^{6}$ Private travel days were extrapolated to the entire population according to the proportion of adults in the total population (travel days among adults divided by the proportion of adults among the total population) (Table 1). To obtain the number of days spent in the community, we subtracted the sum of the number of travel days, the number of days hospitalized, and the number of days spent in nursing homes from the total number of days lived by the German population (calculated as the mean of the total German population during 2004-2006 × 3 years $\times 365.25$ days per year).

During the period from 2004 through 2006, 942 cases of Legionnaires disease with known exposure category were reported in Germany: $102(11 \%)$ cases of nosocomially acquired Legionnaires disease, $23(2 \%)$ cases of Legionnaires

TABLE 1. Incidence, Incidence Rate Ratio, Mortality Rate, and Mortality Rate Ratio of Hospital-Acquired; Nursing Home-Acquired, Travel-Associated, and Community-Acquired Cases of Legionnaires Disease in Germany, 2004-2006

\begin{tabular}{|c|c|c|c|c|c|c|c|}
\hline Legionnaires disease exposure type & $\begin{array}{l}\text { No. of } \\
\text { patients }\end{array}$ & $\begin{array}{l}\text { No. of } \\
\text { days of } \\
\text { exposure, } \\
\text { thousands }\end{array}$ & $\begin{array}{l}\text { Incidence } \\
\text { per } 1 \text { billion } \\
\text { person-days } \\
\text { of exposure }\end{array}$ & $\begin{array}{c}\text { Incidence rate } \\
\text { ratio }^{\mathrm{a}}\end{array}$ & $\begin{array}{c}\text { Case-fatality } \\
\text { ratio, } \\
\text { no. }(\%)\end{array}$ & $\begin{array}{l}\text { Mortality rate } \\
\text { per } 1 \text { billion } \\
\text { person-days } \\
\text { under exposure }\end{array}$ & $\begin{array}{l}\text { Mortality rate } \\
\text { ratio }^{\mathbf{b}}\end{array}$ \\
\hline Hospital acquired (nosocomially acquired) & 102 & $432,241^{c}$ & 236.0 & 36.5 & $13 / 100(13.0)$ & 30.1 & 54.5 \\
\hline Nursing home acquired & 23 & $829,119^{d}$ & 27.7 & 4.3 & $3 / 23(13.0)$ & 3.6 & 6.4 \\
\hline Total healthcare associated & 125 & $1,261,360$ & 99.1 & 15.3 & $16 / 123(13.0)$ & 12.7 & 22.9 \\
\hline Travel associated & 270 & $4,460,527^{\mathrm{e}}$ & 60.5 & 9.4 & $12 / 264(4.6)$ & 2.7 & 4.9 \\
\hline
\end{tabular}

" Calculated by using the incidence of community-acquired Legionnaires disease as the reference.

${ }^{b}$ Calculated by using the mortality rate of patients with community-acquired Legionnaires disease as the reference.

' No. of days hospitalized.

"No. of days spent in nursing homes, calculated as no. of nursing home beds, assuming $100 \%$ occupancy. The no. for 2005 was the only one available, so it was multiplied by 3 to cover the period from 2004 through 2006.

- Travel days is the sum of days spent on occupational travel $(296,000,000)$ and nights spent on private travel by the general population $(4,164,527,000$ $\left.\left[N_{0}\right]\right) . \mathrm{N}_{0}$ was calculated from the no. of nights spent on private travel in the population $>14$ years old $\left(N_{>14 \text { years }}=3,569,000,000\right)$ and the proportion of the population $<15$ years old $(14.3 \%)$ by means of the formula $N_{0}=N_{>14 \text { years }} /(1-0.143)$.

f To obtain the no. of days spent in the community, we subtracted the sum of the no. of travel days, the no. of days hospitalized, and the no. of days spent in nursing homes from the total no. of days lived by the German population (mean of total German population during 2004-2006 $\times 3$ years $\times 365.25$ days per year). 
disease acquired in a nursing home, $270(29 \%)$ cases of travelassociated Legionnaires disease, and $547(58 \%)$ cases of community-acquired Legionnaires disease. The proportion of cases in each category was similar to that of the European data. However, the incidence per 1 billion person-days at risk was 236 for nosocomially acquired Legionnaires disease, 28 for Legionnaires disease acquired in a nursing home, 61 for travel-associated Legionnaires disease, and 7 for communityacquired Legionnaires disease. Using community-acquired Legionnaires disease-the type of exposure with the lowest incidence-as the reference, we found that nosocomially acquired Legionnaires disease had an incidence rate ratio (IRR) of 36.5 , Legionnaires disease acquired in a nursing home had an IRR of 4.3, and travel-associated Legionnaires disease had an IRR of 9.4 (Table 1). Death occurred in 13 patients with nosocomially acquired Legionnaires disease, 3 patients with Legionnaires disease acquired in a nursing home, 12 patients with travel-associated Legionnaires disease, and 47 patients with community-acquired Legionnaires disease, resulting in mortality rates for each category of 30.1, 3.6, 2.7, and 0.6 deaths per 1 billion person-days, respectively. Again, using the mortality rate of patients with community-acquired Legionnaires disease as the reference, we found a mortality rate ratio of 54.5 for patients with nosocomially acquired Legionnaires disease, 6.4 for patients with Legionnaires disease acquired in a nursing home, and 4.9 for patients with travelassociated Legionnaires disease.

We are aware that the estimates of the data in the denominator (days of exposure) are rough, and age-adjusted calculations may lead to different results. Those detailed data were not available to us, however, and we note that numerator data are also affected by inaccuracy because Legionnaires disease of all categories is likely to be underreported, and perhaps differentially underreported in different categories. In conclusion, while the magnitudes of the incidence and mortality rates, as well as the IRRs and mortality rate ratios, should be viewed with caution, these calculations are intended primarily to present a different perspective on the epidemiological characteristics of Legionnaires disease. Using this approach, we found that nosocomially acquired Legionnaires disease has the highest incidence of illness and death among the exposure categories. These findings underscore the importance of nosocomially acquired Legionnaires disease and the need to monitor Legionnaires disease, in particular nosocomially acquired Legionnaires disease, more vigorously. Because nosocomially acquired Legionnaires disease is preventable, these findings lend further support to standing recommendations, such as the recommendation to immediately investigate single cases of nosocomially acquired Legionnaires disease. ${ }^{7,8}$

\section{ACKNOWLEDGMENTS}

Potential conflicts of interest. All authors report no conflicts of interest relevant to this article.

\section{U. Buchholz, MD, MPH; P. Stöcker, MPH;} B. Brodhun, PhD, MPH

From the Robert Koch-Institute, Berlin, Germany.

Address reprint requests to Petra Stöcker, MPH, Department of Infectious Disease Epidemiology, Division 36 Respiratory Diseases, Robert Koch-Institute, DGZ-Ring 1, D-13086 Berlin, Germany (stoeckerp@rki.de). Infect Control Hosp Epidemiol 2010; 31:104-105

(C) 2010 by The Society for Healthcare Epidemiology of America. All rights reserved. 0899-823X/2010/3101-0020\$15.00. DOI: $10.1086 / 648664$

\section{REFERENCES}

1. Ricketts KD, Joseph CA. Legionnaires' disease in Europe 2003-2004. Euro Surveill 2005; 10:256-259.

2. Ricketts KD, Joseph CA. Legionnaires' disease in Europe: 2005-2006. Euro Surveill 2007; 12:article 753. http://www.eurosurveillance.org/ViewArticle .aspx?Articleid $=753$. Published December 1, 2007. Accessed January 12, 2009.

3. Federal Statistical Office, Wiesbaden, Germany. Health. In: Statistisches Jahrbuch der Bundesrepublik Deutschland 2006 [Statistical Yearbook for the Federal Republic of Germany 2006]. Wiesbaden, Germany: Federal Statistical Office; 2006:236.

4. Federal Statistical Office, Wiesbaden, Germany. Health. In: Statistisches Jahrbuch der Bundesrepublik Deutschland 2007 [Statistical Yearbook for the Federal Republic of Germany 2007]. Wiesbaden, Germany: Federal Statistical Office; 2007:237.

5. Federal Statistical Office, Wiesbaden, Germany. Health. In: Statistisches Jahrbuch der Bundesrepublik Deutschland 2008 [Statistical Yearbook for the Federal Republic of Germany 2008]. Wiesbaden, Germany: Federal Statistical Office; 2008:242.

6. Federal Statistical Office, Wiesbaden, Germany. Tourismus in Zahlen 2006 [Tourism in numbers 2006]. 18th ed. Wiesbaden, Germany: Federal Statistical Office; 2007.

7. Lee JV, Joseph C. Guidelines for investigating single cases of Legionnaires' disease. Commun Dis Public Health 2002; 5:157-162.

8. Sehulster L, Chinn RY. Guidelines for environmental infection control in health-care facilities: recommendations of $\mathrm{CDC}$ and the Healthcare Infection Control Practices Advisory Committee (HICPAC). MMWR Recomm Rep 2003; 52(RR-10):1-42. 